\title{
STUDY OF THE POSSIBLE ANTIHYPERTENSIVE AND HYPOLIPIDEMIC EFFECTS OF AN HERBAL MIXTURE ON L-NAME-INDUCED HYPERTENSIVE RATS
}

\author{
MOUCHIRA ABDEL SALAM ${ }^{1}$, BASSANT MM IBRAHIM ${ }^{2}$, SEHAM EL-BATRAN ${ }^{2}$, \\ SOUAD E EL-GENGAIHI ${ }^{3 *}$, DOHA H ABOU BAKER ${ }^{3}$
}

\begin{abstract}
${ }^{1}$ Department of Alternative Medicine, National Research Centre, Dokki, Giza, Egypt. ${ }^{2}$ Department of Pharmacology, National Research Centre, Dokki, Giza, Egypt. ${ }^{3}$ Department of Medicinal and Aromatic Plants, National Research Centre, Dokki, Giza, Egypt. Email: souadgengaihi@hotmail.co.uk
\end{abstract}

Received: 11 April 2016, Revised and Accepted: 16 April 2016

\section{ABSTRACT}

Objective: Hypertension is a chronic medical condition. Diet can improve blood pressure control and decrease the risk of health complication.

Methods: In this study, four plants: Roselle, Marjoram, Chamomile, and Doum were extracted by water. Equal portions of them were mixed. Lethal dose $50 \%$ of the mixture was assayed; the dose which did not cause any mortality was $266.94 \mathrm{mg} / 100 \mathrm{~g}$ body weight. Animals were classified into five groups: Negative control group, positive control group where hypertension was induced by L-name, two groups treated with two doses of the mixture, and a group treated with prazosin as a standard treatment. Treatment of hypertensive rats continued for 4 successive weeks.

Results: Treatment with the mixture showed a significant reduction in blood pressure of hypertensive rats, as well as serum cholesterol, low-density lipoprotein-cholesterol, and urea levels when compared to positive control group.

Conclusion: The results obtained suggest that the aqueous extract is efficient as an antihypertensive and hypolipidemic agent.

Keywords: Rats, Aqueous extract, Hypertension, Hyperlipidemia, L-name.

(C) 2016 The Authors. Published by Innovare Academic Sciences Pvt Ltd. This is an open access article under the CC BY license (http://creativecommons. org/licenses/by/4. 0/) DOI: http://dx.doi.org/10.22159/ajpcr.2016.v9i5.12175

\section{INTRODUCTION}

High blood pressure is called the "silent killer" because it often has no warning signs or symptoms. Hypertension is one of the most important causes of premature death worldwide, and the problem is growing; in 2025, an estimated 1.56 billion adults will be living with hypertension. About nearly one billion people have hypertension and two-thirds of them are in developing countries [1].

There is an association between hyperlipidemia and hypertension as it is prevalent in hypertension [2]. It is worth noting that both hypertension and hyperlipidemia are risk factors for chronic diseases such as cardiovascular diseases (CVDs).

There are different groups of antihypertensive drugs for clinical use including alpha blockers as prazosin which is occasionally prescribed for hypertension and its effect in lowering blood pressure is the modest [3], central adrenergic inhibitors which cause fatigue, sedation, orthostatic or exercise-induced hypotension and frequent incidence of depression at higher doses [4], diuretics and beta blockers which cause hyperlipidemia [5]. Therefore, there is an increasing demand for complementary and alternative medicine with antihypertensive activity and fewer side effects.

Natural herbs have been of interest because of their potential health benefit against CVD. Numerous herbal preparations have been shown to affect blood pressure levels through various mechanisms, although they are usually limited by toxicity or relative lack of efficacy compared with standard medications. The lack of standardization of ingredients and preparation also causes problems.

Roselle is one potential non-pharmacological treatment. In folk medicine, the calyces' infusion is used for the treatment of several conditions including high blood pressure [6].

Furthermore, Kim et al. [7] reported that Marjoram is an aromatic herb of the mint family which originated in Egypt and the Arab
Kingdom; Marjoram is the enhancement of the cardiovascular and circulatory system. It helps by eliminating the common risks associated with CVD through lowering the blood pressure, greatly reducing the risk of hypertension and resultant heart problems and greatly preventing the buildup of cholesterol, reducing risk of hardened arteries so reducing the rate of heart disease and heart attack.

Furthermore, Chamomile is one of the most ancient medicinal herbs known to humankind. It is a member of Asteraceae family and represented by two common varieties, viz., German Chamomile (Chamomilla recutita) and Roman Chamomile (Chamaemel umnobile). The dried flowers of Chamomile contain mono, sesquiterpenoids, and flavonoids contributing to its medicinal properties [8]. Chamomile, which has been used as an herbal medication since ancient times, is still popular today and probably will continue to be used in the future because it contains various bioactive phytochemicals that could provide or induce therapeutic effects. Chamomile can help in improving cardiovascular conditions, stimulate immune system.

Doum fruit, which is rich in flavonoids (polyphenols), saponins, and tannins, is used in folk medicine as it can lower blood pressure in hypertensive patients and blood lipids in a manner that decreases the risk on the cardiovascular system [9].

\section{METHODS}

Materials

Plants

About $1 / 2 \mathrm{~kg}$ of the following plants, the red calyces of Roselle, all herb of Marjoram, flowers of Chamomile, and the outer part of Doum fruits were soaked in cooled water overnight then filtered and reextracted by cooled water till exhaustion. All filtrates of each plant were combined, evaporated under reduced pressure, and then lyophilized. A mixture contains equal weights of each extract was prepared, for animal treatments. 


\begin{abstract}
Animals
Adult male rats (150-175 g), and adult mice of both sexes (18-20 g), were used in the experiments. The animals were obtained from the animal house colony of the National Research Centre, Dokki, Giza, Egypt. The animals were housed in standard metal cages in an air-conditioned room at $22 \pm 3^{\circ} \mathrm{C}, 55 \pm 5 \%$ humidity and provided with standard laboratory diet and water ad libitum. All experimental procedures were conducted in accordance with the guide for care and use of laboratory animals and in accordance with the Ethics Committee of the National Research Centre.
\end{abstract}

\section{Diagnostic kits}

Kits for determination of total cholesterol, triglycerides, high-density lipoprotein (HDL) and low-density lipoprotein (LDL) cholesterol, urea, and creatinine were purchased from Biodiagnostic Company, Egypt.

\section{Apparatus}

Non-invasive blood pressures monitor (Ugo, Basile-Italy) spectrophotometer.

\section{Methods}

\section{Phytochemical screening}

Detection of volatile substances

About $10 \mathrm{~g}$ of the samples were subjected to water distillation $(500 \mathrm{ml}$ water) using Clevenger's apparatus. The distillation was continued for $3 \mathrm{hrs}$ after boiling. The volatile substances were isolated and dried over anhydrous $\mathrm{Na}_{2} \mathrm{SO}_{4}$ according to Guenther [10].

Detection of carbohydrates and/or glycosides

About $1 \mathrm{~g}$ of each powdered sample was extracted with $10 \mathrm{ml}$ of $50 \%$ ethanol. The presence of carbohydrates and/or glycosides in the ethanolic extract was detected using $\alpha$-naphtholsulfuric acid reagent as reported by Lewis and Smith [11]. Formation of a red or dull violet at the interphase of the two layers was a positive test.

\section{Detection of tannins}

The method of Shellard [12] has been used for the detection of tannins in the ethanolic extract by the addition of few drops of $10 \%$ ferric chloride in ethanol reagent. The change of color to bluish black or precipitate indicates the presence of tannins.

\section{Detection of alkaloids}

About $1 \mathrm{ml}$ of the alcoholic extract filtrate was mixed with $2 \mathrm{ml}$ of Dragendoff's reagent; a turbid orange indicates the presence of alkaloids. The confirmation test was done using Mayer's reagent; hence, appearance of yellow precipitate indicates the presence of the alkaloids [13].

\section{Detection of flavonoids}

About $10 \mathrm{~g}$ of the powdered sample was macerated in $50 \mathrm{ml}$ of $1 \% \mathrm{HC} 1$ acid overnight and filtered. Then, $10 \mathrm{ml}$ of the filtrate was rendered alkaline with $\mathrm{NaOH}(1 \mathrm{M})$, and the formation of yellow indicates the probable presence of flavonoids [14].

Furthermore, magnesium/HC1 was added to other parts of ethanolic extract, a red formation indicates the presence of flavanones and/or flavonol [15]

Test for saponins

About $5 \mathrm{~g}$ of the dry powdered sample was macerated in $20 \mathrm{ml}$ distilled water, and the filtrate was shaken vigorously. A persisting froth for about 30 minutes indicates the possible presence of saponins [12].

\section{Detection of sterols}

The presence of unsaturated sterols and/or triterpenes was detected using acetic acid anhydride $(0.3 \mathrm{ml})$-sulfuric acid $(0.5 \mathrm{ml})$ reagent and observed for the formation of a brown ring at the junction of two layers. Green coloration of the upper layer and the formation of deep red in the lower layer would indicate a positive test for steroids and triterpenoids, respectively, as reported by Hanson [16].

Test for phenols

About $2 \mathrm{ml}$ extract was taken into water and warmed at $45-50^{\circ} \mathrm{C}$. Then, $2 \mathrm{ml}$ of $3 \% \mathrm{FeCl}_{3}$ was added. Formation of green or blue will indicate the presence of phenols [17].

\section{Pharmacological study}

a. Toxicological study: Lethal dose $50 \%\left(\mathrm{LD}_{50}\right)$ was determined according to the methods described [18] using groups of 10 mice. The symptoms of toxicity and postmortem findings were recorded within the first 24 hrs post-injection.

b. Blood pressure and lipid profile study:

Animal groups

The animals used were classified into five groups (8 rats each) as follows:

- $1^{\text {st }}$ Group: Negative control rats were given $1 \mathrm{ml}$ tab water orally daily for 4 successive weeks

- $\quad 2^{\text {nd }}$ Group (positive control hypertensive group): Induction of animal model mimicking hypertension using L-name orally in a dose of $50 \mathrm{mg} / \mathrm{kg}$ body weight (b.wt.) daily for 4 successive weeks was done according to Khayyal et al. [19]

- $\quad 3^{\text {rd }}$ Group: Hypertensive rats given $0.09 \mathrm{mg} / \mathrm{kg}$ of prazosin as a standard drug (dose calculated according to Paget and Barnes [20])

- $4^{\text {th }}$ Group: Hypertensive rats given $26.694 \mathrm{mg} / \mathrm{kg}$ of aqueous extract of the mixture of Roselle, Marjoram, Chamomile, and Doum orally daily for 4 successive weeks

- $5^{\text {th }}$ Group: Hypertensive rats given $13.347 \mathrm{mg} / \mathrm{kg}$ of aqueous extract of the mixture orally daily for 4 successive weeks.

\section{Blood pressure measurements}

Systolic blood pressure of animals was indirectly measured at zero time then weekly by non-invasive blood pressure monitor (Ugo, Basile-Italy) from the tail of conscious rats by the tail-cuff technique for which all animals were pre-trained until blood pressure was steadily recorded with minimal stress.

Training was conducted by the method described [21] as follow: Plastic restraint tubes were placed in the animal cages for few days before measurement to allow familiarity. The animals were then restrained in the tubes for 10-20 minutes/day for 5 days prior recording blood pressure. In the tail-cuff technique, animals were warmed for 30 minutes at $29^{\circ} \mathrm{C}$ in a thermostatically controlled heating cabinet (Ugo, Basile-Italy), for better detection of tail artery pulse; the tail was passed through a miniaturized cuff and a tail-cuff sensor.

The pulse was recorded by the sensor during automatic inflation and deflation of the cuff. Systolic and diastolic blood pressure was defined as the cuff inflation and deflation.

Blood pressure of baseline was measured before induction of hypertension at zero time and after induction of hypertension at the end of 4 weeks after using L-name daily, and at the end of treatment period with the mixture Roselle, Marjoram, Chamomile, and Doum given in two doses $(26.694$ and $13.347 \mathrm{mg} / \mathrm{kg}$ ) for 4 successive weeks as well as at the end of treatment with prazosin used as a standard drug for treatment of hypertension.

The average of at least three measurements for each rat was taken at each occasion. Heart rate was recorded automatically.

\section{Biochemical parameters}

At the end of the experimental period ( $24 \mathrm{hrs}$ after last dose of mixture and prazosin), the blood was obtained from all groups of rats which were fasting for $18 \mathrm{hrs}$; after being lightly anesthetized with ether by puncturing retro-orbital plexus [22], the blood was allowed to flow into a clean, dry centrifuge tube and left to stand 30 minutes 
before centrifugation to avoid hemolysis. Then, blood samples were centrifuged for 15 minutes at $2500 \mathrm{rpm}$; the clear supernatant serum was separated and collected by Pasteur pipette into a dry clean tube to use for determination serum levels of total cholesterol according to Richmond [23], triglycerides levels according to Fossati and Prencipe [24], HDL-cholesterol according to Burstein et al. [25], LDL-cholesterol according to Friedewald et al. [26], urea according to Fawcett and Scott [27], and creatinine according to Schirmeister [28].

\section{RESULTS AND DISCUSSION}

\section{Phytochemical screening of plants}

In the present study, chronic consumption of L-name for 4 successive weeks induced hypertension (increase in blood pressure). These findings are in agreement with previous studies demonstrating that L-name treatment increases blood pressure by causing cardiac and renal hypertrophy, nitric oxide deficiency, and oxidative stress $[29,30]$.

L-name also caused a significant increase of the levels of total cholesterol, LDL-cholesterol, and urea and decrease of HDL-cholesterol level. These findings are in agreement with previous results [31] that revealed that hypercholesterolemia and dyslipidemia are associated with the pathogenesis of hypertension induced by chronic L-name intake.

Table 1 represents the phytochemical screening of the four plants included in this investigation. From the Table 1, it was found that all aqueous extracts contain carbohydrate and or glycosides, volatile oils, where Chamomile and Marjoram bear higher content.

Flavonoids were found in all the extract in higher amounts; however, phenols and tannins were found in lesser amounts in all plant extracts except Roselle extract.

Doum contains saponins in higher concentration than other plants. No alkaloids were found in all the plants.

\section{Pharmacological study}

Toxicological study

Symptoms of acute toxicity of the mixture of Roselle, Marjoram, Chamomile, and Doum-exhibited increased of respiration rate, cyanosis of mucous membranes, general depression characterized by apathy, loss of righting reflex, convulsion, and death. The $\mathrm{LD}_{50}$ of aqueous extract of the mixture was found to be $266.94 \mathrm{mg} / 100 \mathrm{~g}$ b.wt. when intraperitoneally injected in mice as shown in Table 2.

\section{Blood pressure records}

The effect of treatment with the mixture of Hibiscus, Marjoram, Chamomile, and Doum given in two doses (26.694 and $13.347 \mathrm{mg} / \mathrm{kg}$ ) for 4 successive weeks and prazosin $(0.09 \mathrm{mg} / \mathrm{kg})$ on systolic blood pressure was shown in Fig. 1 and Table 3. Throughout the duration of the experiment, the negative control group blood pressure did not exhibit any significant change. However, all animals in all groups that were given L-name in a daily dose of $50 \mathrm{mg} / \mathrm{kg}$ for 4 weeks were rendered hypertensive.

By the end of that period, the animals showed a significant rise in systolic blood pressure when compared to the baseline blood pressure of all groups. Blood pressure continued to rise significantly despite cessation of administration of L-name but without giving any antihypertensive for the following 4 weeks after induction of hypertension in the positive control group only. However, the treated groups with prazosin and mixture in both doses showed a significant reduction in blood pressure when compared to positive control group at the same period after treatment for 4 successive weeks. The blood pressure of the groups treated with prazosin and the mixture high dose was significantly reduced to be less than the negative control group at the same with the same duration of treatment.
Table 1: The phytochemical screening of the four plants included in this investigation

\begin{tabular}{lllll}
\hline Test & Marjoram & Doom & Chamomile & Hibiscus \\
\hline Carbohydrates & + & ++ & + & + \\
Steroids & + & + & + & - \\
Volatile oils & ++ & + & ++ & + \\
Saponins & + & ++ & ++ & +++ \\
Flavonoids & ++ & ++ & ++ & +++ \\
Alkaloids & ++ & ++ & ++ & +++ \\
Phenols & + & + & + & ++ \\
Tannin & + & + & + & ++ \\
\hline
\end{tabular}

Table 2: Determination of approximate $\mathrm{LD}_{50}$ for a mixture of aqueous extract "Roselle, Marjoram, Chamomile, and Doum" by Karber method (1931) using constant (1.3)

\begin{tabular}{llllll}
\hline $\begin{array}{l}\text { Dose used } \mathbf{~ m g / 1 0 0 ~ g ~} \\
\text { b.wt }\end{array}$ & M & Reaction & Z & D & Z.D \\
\hline 482.7 & 10 & 10 & - & - & - \\
371.3 & 10 & 8 & 9 & 111.4 & 1002.6 \\
285.6 & 10 & 6 & 7 & 85.7 & 599.9 \\
219.7 & 10 & 4 & 5 & 65.9 & 329.5 \\
169 & 10 & 2 & 3.0 & 50.7 & 152.1 \\
130 & 10 & 1 & 1.5 & 39 & 58.5 \\
100 & 10 & - & 0.5 & 30 & 15 \\
\hline$\sum Z$
\end{tabular}

$\sum$ Z.D $=2157.6$

a.M. $=\mathrm{DM}=\sum \frac{\mathrm{Z} \cdot \mathrm{D}}{\mathrm{M}}=482.7-2157.6 / 10$

$\mathrm{LD}_{50}=266.94 \mathrm{mg} / 100 \mathrm{~g}$ b.wt

Where, aM: Arithmetic mean of $\mathrm{LD}_{50}$, DM: The dose by which all the animal reacted, Z: Half the sum of the positive reacted animals from 2 successive 1 , doses, D: The difference between the numbers of 2 successive doses, M: The number of animals in each group. $\mathrm{LD}_{50}$ : Lethal dose $50 \%$

Tab1e 3: The effect of oral administration of aqueous extract of Roselle, Marjoram, Chamomile, and Doum (26.694 and $13.347 \mathrm{mg} / \mathrm{kg})$ and prazosin $(0.09 \mathrm{mg} / \mathrm{kg})$ on systolic blood pressure in hypertensive rats induced by L-name $(50 \mathrm{mg} / \mathrm{kg})$

\begin{tabular}{llll}
\hline Onset groups & Baseline & $\begin{array}{l}\text { After induction } \\
\text { of hypertension }\end{array}$ & $\begin{array}{l}\text { After treatment } \\
\text { of hypertension }\end{array}$ \\
\hline $\begin{array}{l}\text { Negative control } \\
\text { Positive control }\end{array}$ & $102.1 \pm 2.1$ & $\begin{array}{l}105.8 \pm 2.4 \\
141.6 \pm 7.8^{\#}\end{array}$ \\
Prazosin & $101.6 \pm 17$ & $131.9 \pm 5.1^{\#}$ & $94.47 \pm 5.6^{\# *}$ \\
$(0.09 \mathrm{mg} / \mathrm{kg})$ & & & \\
Mixture & & & $102.0 \pm 5.3^{*}$ \\
$(26.694 \mathrm{mg} / \mathrm{kg})$ & & & $82.35-1-1.94^{\# *}$ \\
Mixture & & & \\
$(13.347 \mathrm{mg} / \mathrm{kg})$ & & &
\end{tabular}

Values represent the mean \pm SE of eight rats for each group. $n=8, p<0.001$. Statistical analysis was done using two-way ANOVA, followed by Bonferroni's test for multiple comparisons. Comparison between groups was done at the same period of treatment for all groups. "Significant different from negative control group, *Significant different from positive control group. SE: Standard error

Results reveal that the aqueous extract is efficient as antihypertensive agent by significantly and dose-dependently preventing the increase of blood pressure and blood lipids in L-name-induced hypertensive rats. Indeed, various findings and the phytochemical screening done in this investigation have shown the presence of flavonoids, tannin, and phenolic compounds in the different medicinal plants constitute the mixture $[7,8,32,33]$. Which may explain the antihypertensive effects of this extract as the above phytochemical components are known for their vasorelaxant and cardioprotective activities. 


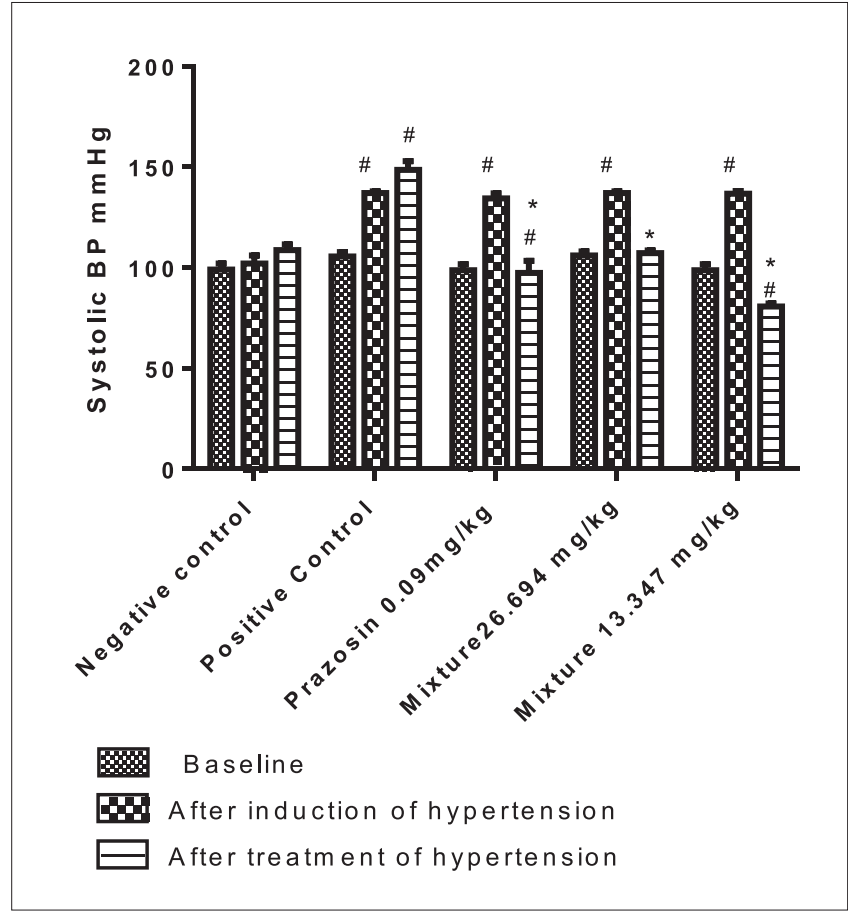

Fig. 1: The effect of oral administration of aqueous extract of Hibiscus, Marjoram, Chamomile, Hyphaene thebaica (26.694 and $13.347 \mathrm{mg} / \mathrm{kg})$ and prazosin $(0.09 \mathrm{mg} / \mathrm{kg})$ on systolic blood pressure in hypertensive rats induced by L-name $(50 \mathrm{mg} / \mathrm{kg})$. Values represent the mean \pm standard error of eight rats for each group, $n=8, p<0.001$. Statistical analysis was done using two-way ANOVA followed by Bonferroni's test for multiple comparisons.

Comparison between groups was done at the same period of treatment for all groups. "Significant different from negative control group, *Significant different from positive control group

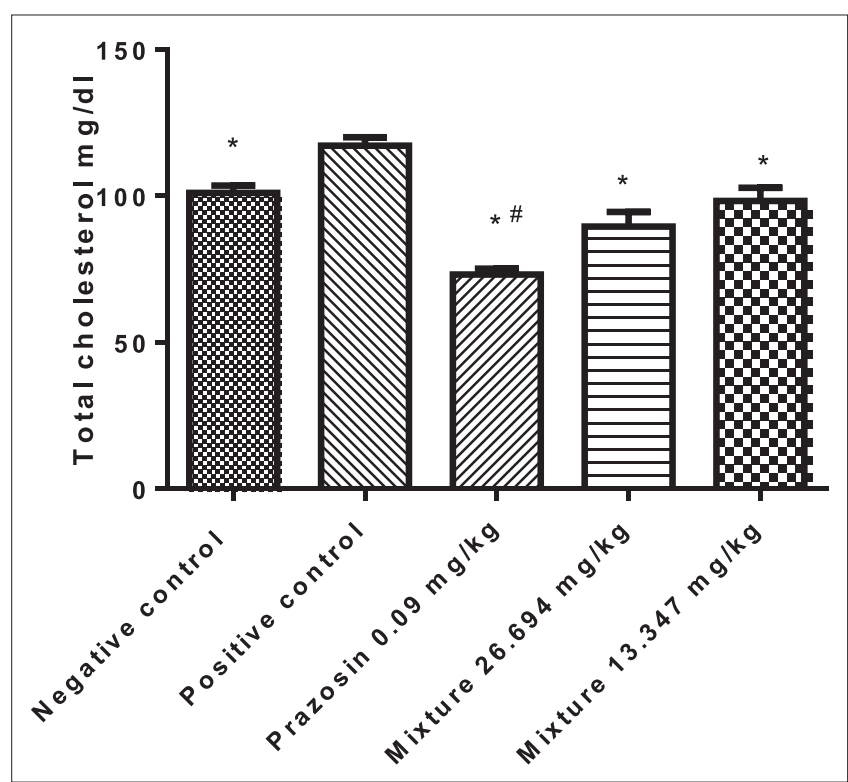

Fig. 2: The effect of oral administration of aqueous extract of Hibiscus, Marjoram, Chamomile, Hyphaene thebaica (26.694 and $13.347 \mathrm{mg} / \mathrm{kg})$ and prazosin $(0.09 \mathrm{mg} / \mathrm{kg})$ on serum levels of total cholesterol in hypertensive rats induced by L-name, $50 \mathrm{mg} / \mathrm{kg}$ ). Values represent the mean \pm standard error of eight rats for each group, $n=8, p<0.001$. Statistical analysis was done using one-way ANOVA followed by Tukey for multiple comparisons. "Significant different from negative control group, *Significant different from positive control group

\section{Biochemical parameters}

Regarding the effects of the mixture on the biochemical parameters which are shown in Figs. 2-7 and Table 4. L-name produced a significant elevation in serum cholesterol, LDL-cholesterol, and urea and reduction

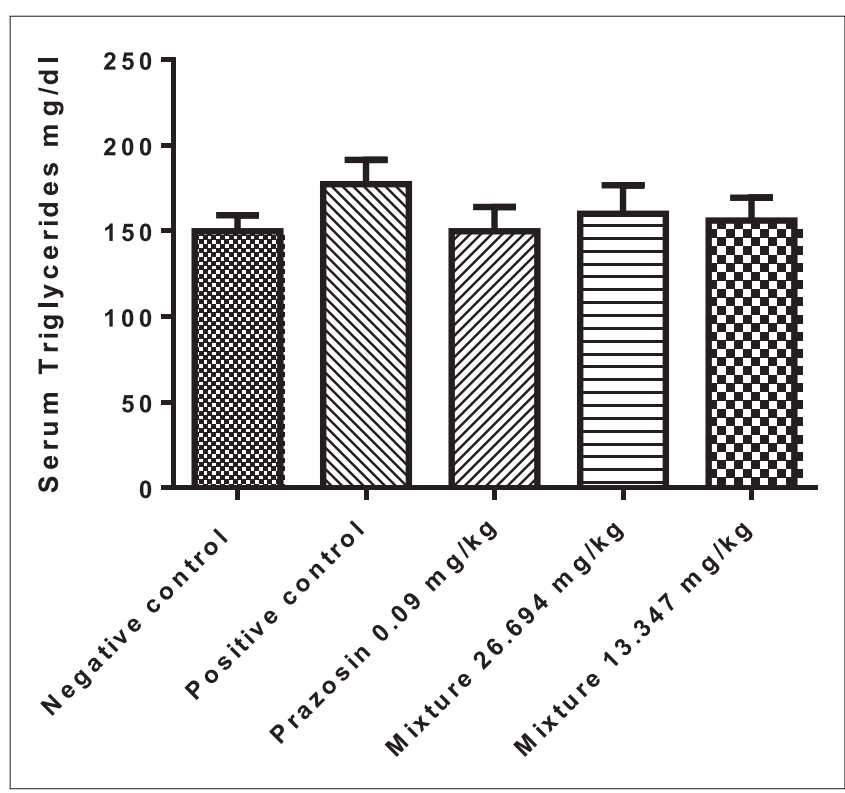

Fig. 3: The effect of oral administration of aqueous extract of Hibiscus, Marjoram, Chamomile, Hyphaene thebaica (26.694 and

$13.347 \mathrm{mg} / \mathrm{kg})$ and prazosin $(0.09 \mathrm{mg} / \mathrm{kg})$ on serum levels of triglycerides in hypertensive rats induced by L-name $(50 \mathrm{mg} / \mathrm{kg})$. Values represent the mean \pm standard error of eight rats for each group, $n=8$. Statistical analysis was done using one-way ANOVA followed by Tukey for multiple comparisons

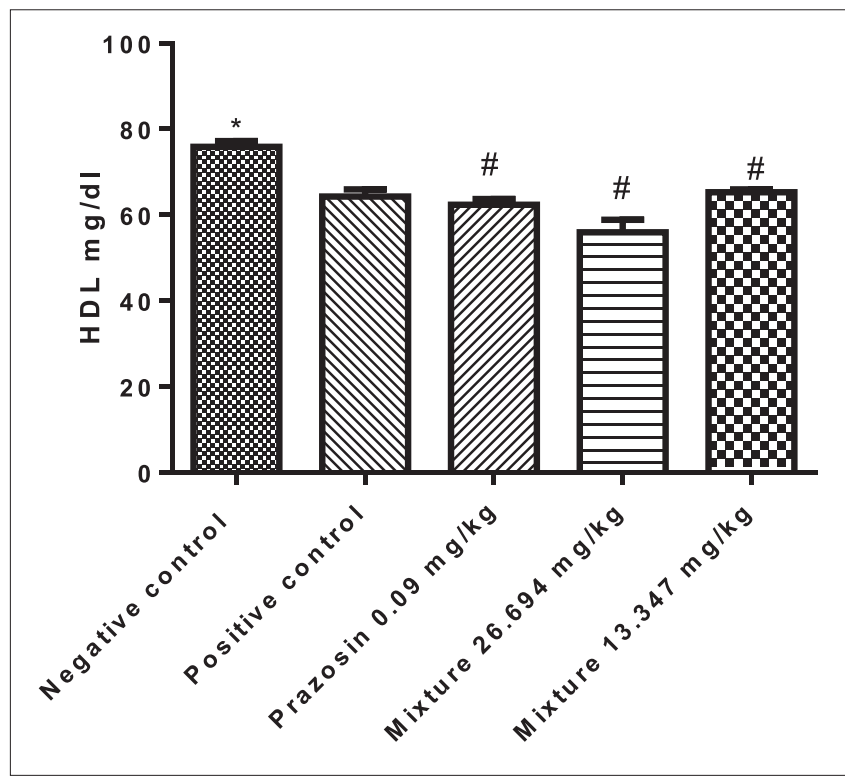

Fig. 4: The effect of oral administration of aqueous extract of Hibiscus, Marjoram, Chamomile, Hyphaene thebaica (26.694 and $13.347 \mathrm{mg} / \mathrm{kg})$ and prazosin $(0.09 \mathrm{mg} / \mathrm{kg})$ on serum levels of high-density lipoprotein-cholesterol in hypertensive rats induced by L-name $(50 \mathrm{mg} / \mathrm{kg})$. Values represent the mean \pm standard error of eight rats for each group, $n=8, p<0.001$. Statistical analysis was done using one-way ANOVA followed by Tukey for multiple comparisons. "Significant different from negative control group, *Significant different from positive control group 
Table 4: The effect of oral administration of aqueous extract of Roselle, Marjoram, Chamomile, and Doum (26.694 and $13.347 \mathrm{mg} / \mathrm{kg})$ and prazosin $(0.09 \mathrm{mg} / \mathrm{kg})$ on serum levels of cholesterol, triglycerides, HDL, LDL, urea, and creatinine in hypertensive rats induced by L-name $(50 \mathrm{mg} / \mathrm{kg})$

\begin{tabular}{|c|c|c|c|c|c|}
\hline \multirow[t]{2}{*}{ Parameter } & \multicolumn{5}{|l|}{ Group } \\
\hline & $\begin{array}{l}\text { Negative } \\
\text { control }\end{array}$ & $\begin{array}{l}\text { Positive } \\
\text { control }\end{array}$ & $\begin{array}{l}\text { Prazosin } \\
0.09 \mathrm{mg} / \mathrm{kg}\end{array}$ & $\begin{array}{l}\text { Mixture } \\
26.694 \mathrm{mg} / \mathrm{kg}\end{array}$ & $\begin{array}{l}\text { Mixture } \\
13.347 \mathrm{mg} / \mathrm{kg}\end{array}$ \\
\hline Cholesterol mg/dl & $101.1 \pm 2.47$ & $117.2 \pm 2.85^{\#}$ & $73.18 \pm 1.95^{\# *}$ & $89.55 \pm 4.98^{*}$ & $98.295 \pm 4.56^{*}$ \\
\hline Triglycerides mg/dl & $149.8 \pm 9.41$ & $177.4 \pm 14.23$ & $150 \pm 14.03$ & $160 \pm 16.82$ & $156.2 \pm 13.23$ \\
\hline HDL-cholesterol mg/dl & $75.9 \pm 1.28$ & $64.25 \pm 1.71^{\#}$ & $62.41 \pm 1.31^{\#}$ & $55.98 \pm 2.88^{\#}$ & $65.33+0.63^{\#}$ \\
\hline LDL-cholesterol mg/d1 & $-2.86 \pm 0.67$ & $15.57 \pm 0.88^{\#}$ & $-23.72 \pm 1.4^{\# *}$ & $3.24 \pm 0.41^{\# *}$ & $1.8 \pm 0.62^{\# *}$ \\
\hline Creatinine mg/dl & $1.89 \pm 0.09$ & $1.88 \pm 0.06$ & $1.65 \pm 0.04$ & $1.89 \pm 0.06$ & $1.88 \pm 0.11$ \\
\hline Urea $\mathrm{mg} / \mathrm{dl}$ & $25.29 \pm 0.27$ & $29.08 \pm 1.43^{\#}$ & $18.38 \pm 0.23^{\# *}$ & $22.39 \pm 0.65^{*}$ & $24.57 \pm 1.14^{*}$ \\
\hline
\end{tabular}

Values represent the mean \pm SE of eight rats for each group. $n=8, p<0.001$. Statistical analysis was done using one-way ANOVA, followed by Tukey for multiple comparisons. "Significant different from negative control group, *Significant different from positive control group. LDL: Low-density lipoprotein, SE: Standard error, HDL: High-density lipoprotein

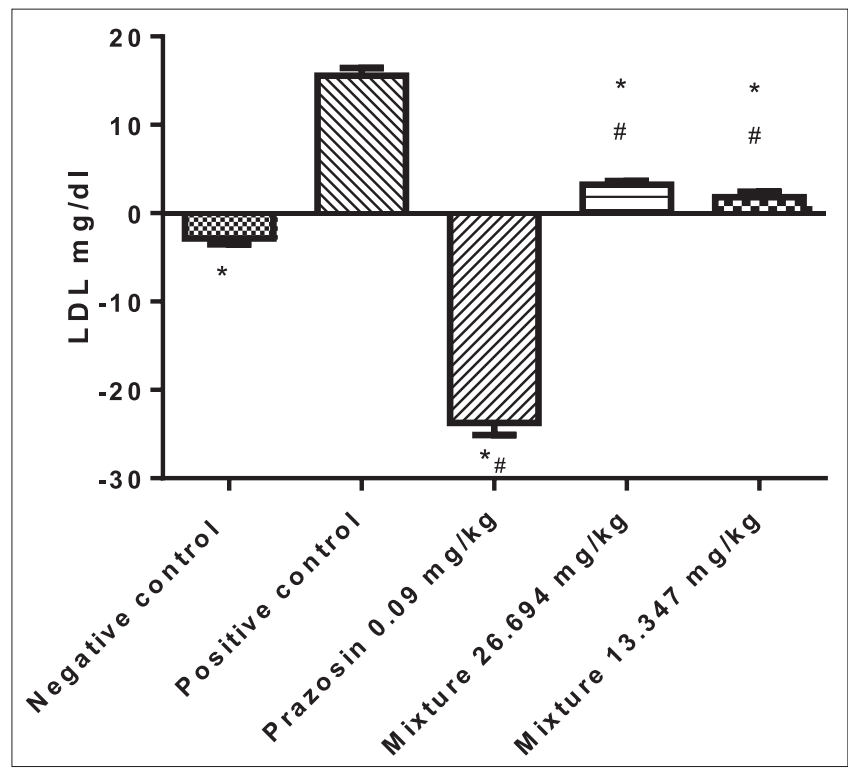

Fig. 5: The effect of oral administration of aqueous extract of Hibiscus, Marjoram, Chamomile, Hyphaene thebaica $(26.694$ and $13.347 \mathrm{mg} / \mathrm{kg})$ and prazosin $(0.09 \mathrm{mg} / \mathrm{kg})$ on serum levels of low-density lipoprotein-cholesterol in hypertensive rats induced by L-name $(50 \mathrm{mg} / \mathrm{kg})$. Values represent the mean \pm standard of eight rats for each group, $n=8, p<0.001$.

Statistical analysis was done using one-way ANOVA, followed by Tukey for multiple comparisons. "Significant different from negative control group, ${ }^{*}$ Significant different from positive control group

in serum HDL-cholesterol level. On the other hand, treatment with the mixture of Hibiscus, Marjoram, Chamomile, and Doum given in two doses (26.694 and $13.347 \mathrm{mg} / \mathrm{kg}$ ) and prazosin $0.09 \mathrm{mg} / \mathrm{kg}$ for 4 successive weeks showed a significant reduction in serum cholesterol, LDLcholesterol, and urea levels when compared to positive control group. In addition, prazosin reduced serum cholesterol, LDL-cholesterol, and urea levels significantly less than the negative control group. However, the mixture in both doses showed a significant increase in LDL level significantly more than the negative control group. All treated groups showed a significant reduction in HDL-cholesterol level when compared to negative control group. There was no significant change in serum levels of triglycerides or creatinine throughout the study.

Administration of the aqueous extracts in a dose-dependent manner provided a beneficial action on rat lipid profile with regard to the reduction of total cholesterol and LDL-cholesterol. The lipidlowering potential of the extract may be attributed to the presence

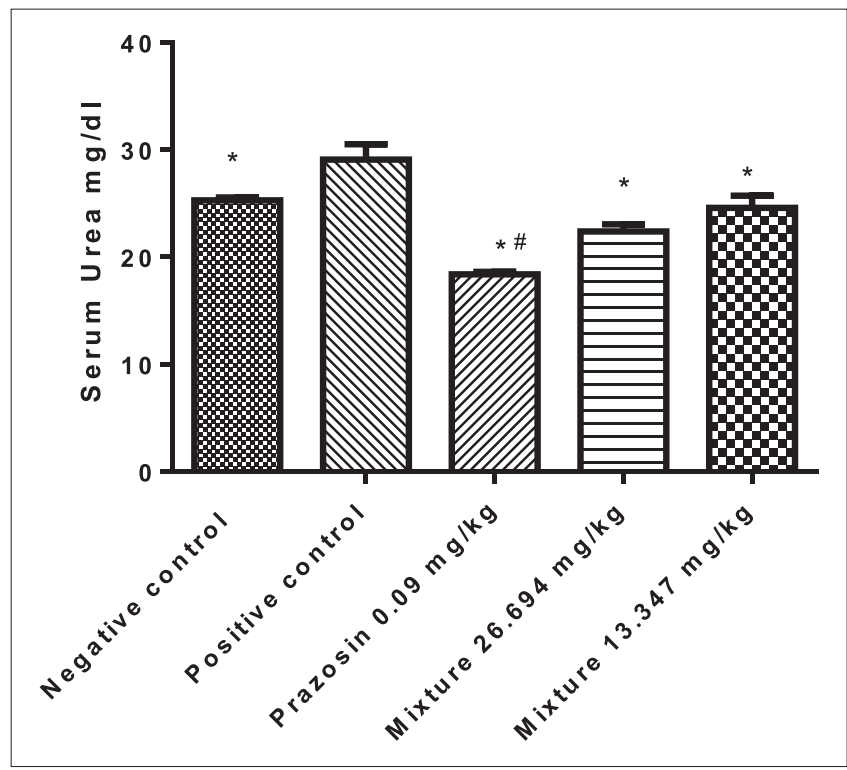

Fig. 6: The effect of oral administration of aqueous extract of Hibiscus, Marjoram, Chamomile, Hyphaene thebaica (26.694 and $13.3478 \mathrm{mg} / \mathrm{kg})$ and prazosin $(0.09 \mathrm{mg} / \mathrm{kg})$ on serum levels of urea in hypertensive rats induced by $\mathrm{L}-\mathrm{name}(50 \mathrm{mg} / \mathrm{kg})$ values represent the mean \pm standard error of eight rats for each group, $\mathrm{n}=\mathbf{8}, \mathbf{p}<\mathbf{0 . 0 0 1}$. Statistical analysis was done using one-way ANOVA, followed by Tukey for multiple comparisons. "Significant different from negative control group, *Significant different from positive control group

of phytochemical constituents such as flavonoids, saponins, and tannins [32,34]. Flavonoids are reported to lower LDL-cholesterol concentrations in hypercholesterolemic animals [35]. Saponins are reported to inhibit pancreatic lipase activity in high-fat diet fed mice leading to greater fat excretion due to reduced intestinal absorption of dietary fats [36]. Similarly, tannins are recognized for their ability to inhibit lipid absorption [37].

\section{CONCLUSION}

This study demonstrates the promising effect of the aqueous extract prepared by mixing the Roselle, Marjoram, Chamomile, and Doum together in preventing L-name-induced hypertension in rats. Moreover, the extract improved of lipid profile and kidney function tests. Thus, this study provides validation of the experimental use of these herbs in the management of hypertension associated with hyperlipidemia. However, further clinical studies are needed to determine the exact effect of these extracts on humans. 


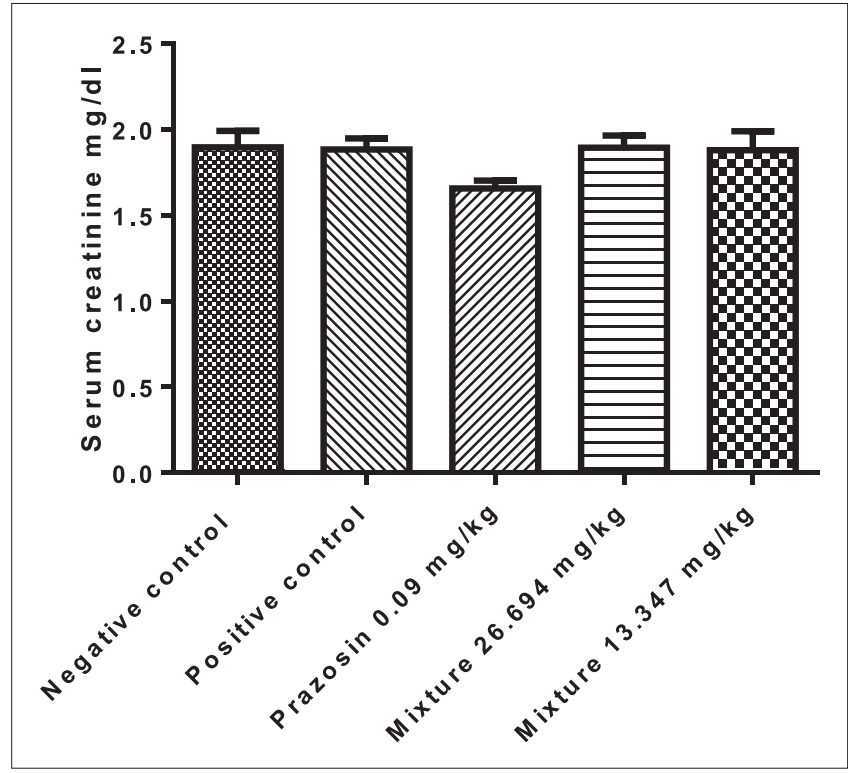

Fig. 7: The effect of oral administration of aqueous extract of Hibiscus, Marjoram, Chamomile, Hyphaene thebaica (26.694 and $13.347 \mathrm{mg} / \mathrm{kg})$ and prazosin $(0.09 \mathrm{mg} / \mathrm{kg})$ on serum levels of creatinine in hypertensive rats induced by L-name $(50 \mathrm{mg} / \mathrm{kg})$. Values represent the mean \pm standard error of eight rats for each

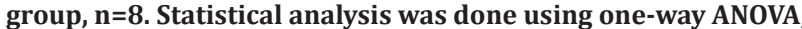
followed by Tukey for multiple comparisons

\section{REFERENCES}

1. World Health Organization. Regional Office for Southeast Asia Hypertension Fact Sheet. Available from: http://www.searo.who.int/ linkfiles/non_communicable_diseases_hypertension-fs.pdf. [Last accessed on $\overline{2} 012 \mathrm{Apr}$ ].

2. Ames RP. Hyperlipidemia in hypertension: Causes and prevention. Am Heart J 1991;122(4):1219-24.

3. Heran BS, Galm BP, Wright JM. Blood pressure lowering efficacy of alpha blockers for primary hypertension. Cochrane Database Syst Rev 2009;7(4):CD004643.

4. Finnerty FA Jr, Davidov M, Mroczek WJ, Gavrilovich L. Influence of extracellular fluid volume on response to antihypertensive drugs. Circ Res 1970;27 1 Suppl 1:71-82.

5. Chait A, Brunzell JD. Acquired hyperlipidemia (secondary dyslipoproteinemias). Endocrinol Metab Clin North Am 1990;19(2):259-78.

6. Wahabi HA, Alansary LA, Al-Sabban AH, Glasziuo P. The effectiveness of Hibiscus sabdariffa in the treatment of hypertension: A systematic review. Phytomedicine 2010;17(2):83-6.

7. Kim IH, Kim C, Seong K, Hur MH, Lim HM, Lee MS. Essential oil inhalation on blood pressure and salivary cortisol levels in prehypertensive and hypertensive subjects. Evid Based Complement Alternat Med 2012;2012:984203.

8. Srivastava JK, Shankar E, Gupta S. Chamomile: A herbal medicine of the past with bright future. Mol Med Rep 2010;3(6):895-901.

9. El-Gendy AA, El-Mileegy A, Ghyaty ED, Malek HA, El-Hamid M, Amany A. The beneficial dietary hypotensive and hypolipidaemic effects of Hyphaene thebaica (Doum). Int J Altern Med 2008;7(1):1.

10. Guenther E. The Essential Oils. Vol. 1. New York: D. Van-Nostrands Co.; 1953. p. 526-48

11. Lewis H, Smith C. Sugar alcohols in fungi and green plants. Methods of detection and estimation. New Phytol 1967;66:185-204.

12. Shellard E. Practical Plant Chemistry. London: London Ritman Medical Publishing Co., Ltd.; 1957. p. 34-80.
13. Harborne JB. Phytochemicals Methods. London: Chapman and Hall Ltd.; 1973. p. 49-188

14. Trease GE, Evans WC. Pharmacognosy. $11^{\text {th }}$ ed. London: Bailliere Tindall: 1989. p. 45-50.

15. Shinoda J. Color reactions of flavone and flavonol derivatives. J Pharm Soc 1928;48:214-20.

16. Hanson JR. In: Newman AA, editor. Chemistry of Terpenes and Terpenoids. New York: Academic Press; 1972. p. 155-206.

17. Sofowara A. Medicinal Plants and Traditional Medicine in Africa. $3^{\text {rd }}$ ed. Nigeria: Spectrum Books Ltd.; 1993. p. 150-153.

18. Karber G. Contribution to the collective treatment of pharmacological serial experiments. Arch Exp Pathol Pharm 1931;162:480-2.

19. Khayyal MT, el-Ghazaly MA, Abdallah DM, Nassar NN, Okpanyi SN, Kreuter MH. Blood pressure lowering effect of an olive leaf extract (Olea europaea) in L-NAME induced hypertension in rats. Arzneimittelforschung 2002;52(11):797-802.

20. Paget GE, Barnes JM. Evaluation of drug activities. In: Lawrence DR, Bacharach AL, editors. Pharmacometics. Vol. 1. New York: Academic Press; 1964. p. 161.

21. Irvine RJ, White J, Chan R. The influence of restraint on blood pressure in the rat. J Pharmacol Toxicol Methods 1997;38:157-62.

22. Sorg DA, Buckner B. A simple method of obtaining venous blood from small laboratory animals. Proc Soc Exp Biol Med 1964;115:1131-2.

23. Richmond W. Preparation and properties of a cholesterol oxidase from Nocardia sp. and its application to the enzymatic assay of total cholesterol in serum. Clin Chem 1973;19(12):1350-6.

24. Fossati P, Prencipe L. Serum triglycerides determined colorimetrically with an enzyme that produces hydrogen peroxide. Clin Chem 1982;28(10):2077-80.

25. Burstein M, Scholnick HR, Morfin R. Rapid method for the isolation of lipoproteins from human serum by precipitation with polyanions J Lipid Res 1970;11(6):583-95.

26. Friedewald WT, Levy RI, Fredrickson DS. Estimation of the concentration of low-density lipoprotein cholesterol in plasma, without use of the preparative ultracentrifuge. Clin Chem 1972;18(6):499-502.

27. Fawcett JK, Scott JE. A rapid and precise method for the determination of urea. J Clin Pathol 1960;13:156-9.

28. Schirmeister J. Creatinine forms a colored complex with picrate in an alkaline medium. Dtsch Med Wschr 1964;89:1018-640.

29. Liener IE. Toxic Constituents of Plant Food Stuffs. $2^{\text {nd }}$ ed. New York: Academic Press; 1980. p. 286

30. Sung JH, Jo YS, Kim SJ, Ryu JS, Kim MC, Ko HJ, et al. Effect of lutein on L-NAME-induced hypertensive rats. Korean J Physiol Pharmacol 2013;17(4):339-45.

31. Bachmann S, Mundel P. Nitric oxide in the kidney: Synthesis, localization, and function. Am J Kidney Dis 1994;24(1):112-29.

32. Bilanda DC, Dimo T, Dzeufiet Djomeni PD, Bella NM, Aboubakar OB, Nguelefack TB, et al. Antihypertensive and antioxidant effects of Allanblackia floribunda Oliv. (Clusiaceae) aqueous extract in alcohol- and sucrose-induced hypertensive rats. J Ethnopharmacol 2010;128(3):634-40.

33. Koffi NF, Marie-Solange T, Emma AA, Noel ZG. Ethno botanica study of plants used to treat arterial hypertension, in traditional medicine, by abbey and Krobou Population of Agboville. Eur J Sci Resvol 2009;35:85-98.

34. El-Gendy AA, El-Mileegy A, Ghyaty ED, Malek HA, El-Hamid M, Amany A. The beneficial dietary hypotensive and hypolipidaemic effects of Hyphaene thebaica (Doum). Int J Altern Med 2009;7:1.

35. Minato K, Miyake Y, Fukumoto S, Yamamoto K, Kato Y, Shimomura Y, et al. Lemon flavonoid, eriocitrin, suppresses exercise-induced oxidative damage in rat liver. Life Sci 2003;72(14):1609-16.

36. Daniel RS, Devi KS, Augusti KT, Sudhakaran Nair CR. Mechanism of action of antiatherogenic and related effects of Ficus bengalensis Linn. flavonoids in experimental animals. Indian $\mathrm{J}$ Exp Biol 2003;41(4):296-303.

37. Han LK, Zheng YN, Xu BJ, Okuda H, Kimura Y. Saponins from platycodi radix ameliorate high fat diet-induced obesity in mice. J Nutr 2002;132(8):2241-5. 